\title{
Weathering mechanism of red discolorations on Limestone object: a case study from Lingyan Temple, Jinan, Shandong Province, China
}

\author{
Jianrui Zha', Shuya Wei ${ }^{1 *}$, Chuanchang Wang ${ }^{2}$, Zhimin $\mathrm{Li}^{1}$, Youzhen $\mathrm{Cai}^{2}$ and Qinglin $\mathrm{Ma}^{3^{*}}$ (D)
}

\begin{abstract}
Red discolorations are an effloresce phenomenon detect on the surface of stone objects and considered as damage factor in both esthetic and conservation points of view. It is very difficult to remove and seldom report about their weathering mechanism. Recently, numerous of red discolorations have affected the limestone objects of Lingyan Temple in Shandong province, one of the most important building materials in China. In order to set up the appropriate conservation remedy, it is essential to identify the origin, characteristics, composition, and the formation process of red discolorations. Several analytical and investigation techniques, such as X-ray fluorescence spectroscopy (XRF), X-ray diffraction (XRD), Micro-Raman spectroscopy (Raman), Fourier transform infrared spectroscopy (FTIR), scanning electron microscopy (SEM) equipped with energy dispersive spectrometer (EDS) were used to better understand the red discolorations. The results demonstrated that the discolorations on limestone surface have been caused by carbonic acid weathering process. The red discolorations consisted mainly of kutnohorite $\left(\mathrm{Ca}(\mathrm{Fe}, \mathrm{Mg}, \mathrm{Mn}) \mathrm{CO}_{3}\right)$ and iron oxides. They showed tabular, lamellar, and granular morphologies, which originated from the in situ carbonic acid weathering of kutnohorite. After rainfall, the $\mathrm{Ca}, \mathrm{Mg}, \mathrm{Mn}$ ions with relatively high solubility were primarily leached from carbonatite phases. It was resulting in the sedimentation of red iron oxides through a chemical reaction and physical adhesion. Based on those analyses, a chelating agent (ethylenediamine tetraacetic acid disodium salt) was chosen to remove theses red discolorations on the stone object.
\end{abstract}

Keywords: Lingyan Temple, Limestone artifact, Red discoloration, Raman, Cleaning, Conservation

\section{Introduction}

Stone objects are the most important carriers of cultural information. Most of them have gone through natural and anthropogenic damages over an extended period of time. According to the research results, the influent factors of the weathering can be divided into three categories of physical, chemical, and biological factors [1].

\footnotetext{
*Correspondence: sywei66@hotmail.com; qinglinma226@126.com 1 Institute of Cultural Heritage and History of Science \& Technology, University of Science and Technology Beijing, Beijing 100083, China ${ }^{3}$ International Joint Research Laboratory of Environmental and Social Archaeology, Shandong University, Qingdao 266237, Shandong Province, China

Full list of author information is available at the end of the article
}

The chemical and biological factors were considered to be the cause of discoloration on stone objects, such as blackening, whitening, and reding. These coloring changes cause not only esthetical interference, but also induce secondary damage to stone objects $[2,3]$. Thus, it is necessary to find a scientific cleaning method to remove the discolorations, yet this cleaning process must consider the weathering mechanism of the stone objects [4]. Red discolorations are not so common on the stone surface compared with the blackening and whitening phenomenon. The discoloring substances have various morphologies, and they present a rigid, dense, and thick crust or a thin layer of microparticle deposits, which does not easily wash out. One of the earliest documented about these chromatic alteration phenomena dates back 
to the Certosa façade (1844). Through microbiological analyses of the marble samples, they attributed the chromatic alteration to the presence of the red-pigmented microorganisms [5]. The subsequent microbiological analysis discussed the influence of microbial melanin on stone monuments [6]. In some research, the inclusion of red pigments in biomineralization products considered to be the cause of the red staining [7]. Studies carried out by micro-Raman spectroscopy showed the presence of minium $\left(\mathrm{Pb}_{3} \mathrm{O}_{4}\right)$, which confirmed the inorganic substance [8]. Subsequently, a series of research shows that red discoloration critically depends on the environment bacteria, decorate pigment, and human intervention [9]. The chromatic alteration process includes three parts: (a) enzymatic decolorization of bacterial pigments [10], (b) atmospheric attack of lead building components [11], and (c) production of hematite through washing and leaching of alkaline silicates [12]. The various morphologies and composites of the red discolorations make it more difficult to find out its causes and prevention, as well as a protection method. In order to set up the appropriate conservation remedy, it is important to identify the origins, characteristics, and composition of the red discolorations. However, most of the current data only reported the discoloring substance and surface morphology of red discolorations. Their chemical reaction, influencing factor, and a detail description of the weathering process is practically missing in the literature.

The Lingyan Temple (灵岩寺) is an integral part of Taishan (泰山) world's natural and cultural heritage, which presents a large number of the stone object with red discolorations on the surface. According to tradition, the temple was founded in Yongxing reign period (357358 AD) during the Eastern Jin Dynasty by an Indian monk, who named Lang in Chinese. The temple further gained a great reputation during the Northern Wei (386-534 AD) and prospered in the dynasties of Tang and Song, with a history of more than 1600 years. Nonetheless, its prominence has not saved the temple from the events of exterminating Buddhism, which caused the temple to be rebuilt at least twice since then. The current building was established in the Tang dynasty (627-649 $\mathrm{AD})$ and considered to be one of the most famous temples in China [13]. The oldest surviving stone sculpture exposed out of doors carved from bedrocks in Tai mountain during $727 \mathrm{CE}$. Some research on the stone object deterioration in this area suggested that the increasingly severe air pollution accelerated the stone decay [14]. Pollutants can be present as gas particles, sulfur and carbon dioxides, nitrogen dioxides, sulfurous and sulfuric anhydrides [15]. Among them, carbon dioxide $\left(\mathrm{CO}_{2}\right)$ was the most common corrosive agent in stone object weathering. The water-soluble gas reacts with moisture and then dissolves minerals to form carbonate and bicarbonate ions responsible for the Karst region [16]. Temperature, gas concentration, and relative humidity are the critical factors for the chemical weathering of stone objects [17]. The weathering process is especially strong when minerals are associated with carbonate rocks because it dissolved in surface water to form colloidal particles [18]. Flocculation, recrystallization, and ions migration can accelerate stone decay, resulting in dirtiness [19]. Previous research has established the description and classification of those features [20], and several studies have documented the red discoloration on stone monuments are generated to the biological or inorganic origin. Redpigmented microorganisms and lead compounds have contributed to the weathering process [21]. Besides, the alkaline mortar, acidic water, atmospheric agents, microorganisms, and bacteria also play an important role in the weathering process. Some of them prove the direct link between discolorations process and deterioration on the stone surface, which is often involved in solution penetration [22]. The formation of severe pitting and interconnected deep holes provides a location for pollutant accumulation and thus form a discoloration on the surface of stone objects [23]. Therefore, this ancient heritage site offers the opportunity to investigate the weathering mechanism of the red discolorations on stone objects.

In this paper, we identify the weathering mechanism of red discolorations based on qualitative, quantitative, morphological, and environmental information. Meanwhile, the chemical cleaning method was tested to remove the red discolorations from stone objects in Lingyan temple.

\section{Background of the study area Historical}

Lingyan Temple in Shandong province has a history of more than 1600 years. During this period, monks, local officials as well as scholars left many stone inscriptions in the temple. According to their shape and structure, these inscriptions are divided into five types: tablet, epigraph, cliff, statue, and monument. Most of them record the managerial system, economy, and culture of the Lingyan temple, and have been widespread in the surrounding area. The monuments statues of the Lingyan temple are concentrated in three locations, which are Thousand Buddha Hall (千佛殿), BanZhou hall (般舟殿) and Five Flower Pavilion (五花阁). As far as the inscription is concerned, prayer, poetry, and scripture are the main components, especially the scripture. The scripture monuments near Thousand Buddha Hall was a construction project of Flower Pavilion and was instituted under the direction of abbot Qionghuan (琼环) in the late Song Dynasty (1056-1063 AD). It was constructed in the 
Ming Dynasty (1436-1449 AD) by a monk named Zhiang (志昂), and was rebuilt in the Qing Dynasty (14361499 AD). However, we do not know what the scripture recorded because one fire almost completely destroyed the monuments.

\section{Geography}

The stone sculptures at the Lingyan Temple are located in Changqing District of Jinan city (济南市), Shandong Province, China, and the geographic location is shown in Fig. 1a. It is approximately $6 \mathrm{~km}$ from the urban area and has a central position of approximately $116^{\circ} 59^{\prime}$ east longitude and $36^{\circ} 21^{\prime}$ north latitude (Fig. 1a, b). The tallest statue is $10 \mathrm{~m}$ high, while the smallest is $0.6 \mathrm{~m}$. They were carved into the cliff and placed on the floor. The location place of the stone objects includes parts of nine spots, and the red discolorations are mainly found near Thousand Buddha Hall (Fig. 1c). All of them remained a vertical trace and presented a rigid deposit that is strongly adhered to the stone monument surface (Fig. 1d).

\section{Weather and climate}

The Lingyan Temple is located in the northwest region of Tai mountain, which belongs to a sub-humid warm temperate continental monsoon climate. It is characterized as a warm climate, abundant rainfall, and four distinctive seasons. In the last 5 years, the temperature has ranged from maxima of $39.1{ }^{\circ} \mathrm{C}$ in the summer to minima of $-12.9{ }^{\circ} \mathrm{C}$ during the winter (Fig. 2). The region receives an average of $715.4 \mathrm{~mm}$ rain per year, and the rainfall distribution is mainly in June, July, and August. Besides, the annual average humidity is $56 \%$ Relative Humidity (RH), and a maximum of $82 \% \mathrm{RH}$ in November. Furthermore, the dominant wind throughout the year is southwest directed, and southeasterly wind prevails in the summer. The annual average wind speed is $2.3 \mathrm{~m} / \mathrm{s}$, and the maximum wind speed is $13.9 \mathrm{~m} / \mathrm{s}$ [24]. The above environment parameter and a relatively higher location with well-developed vegetation determinate a damp foggy microclimate, which provides sufficient water (i.e. rain, moisture) for stone objects forming wet deposits.

\section{Surface weathering features}

In the red discoloration area, a variety of solutional features, specifically the vertical trace, was detected. At some sites, the color change occurs on the vertical surface of the monument (Fig. 3a). At other sites, the color variation occurs on the horizontal surface of the sculpture (Fig. 3b). Most of them presented thick and rigid crusts that are strongly adhered to the stone surface

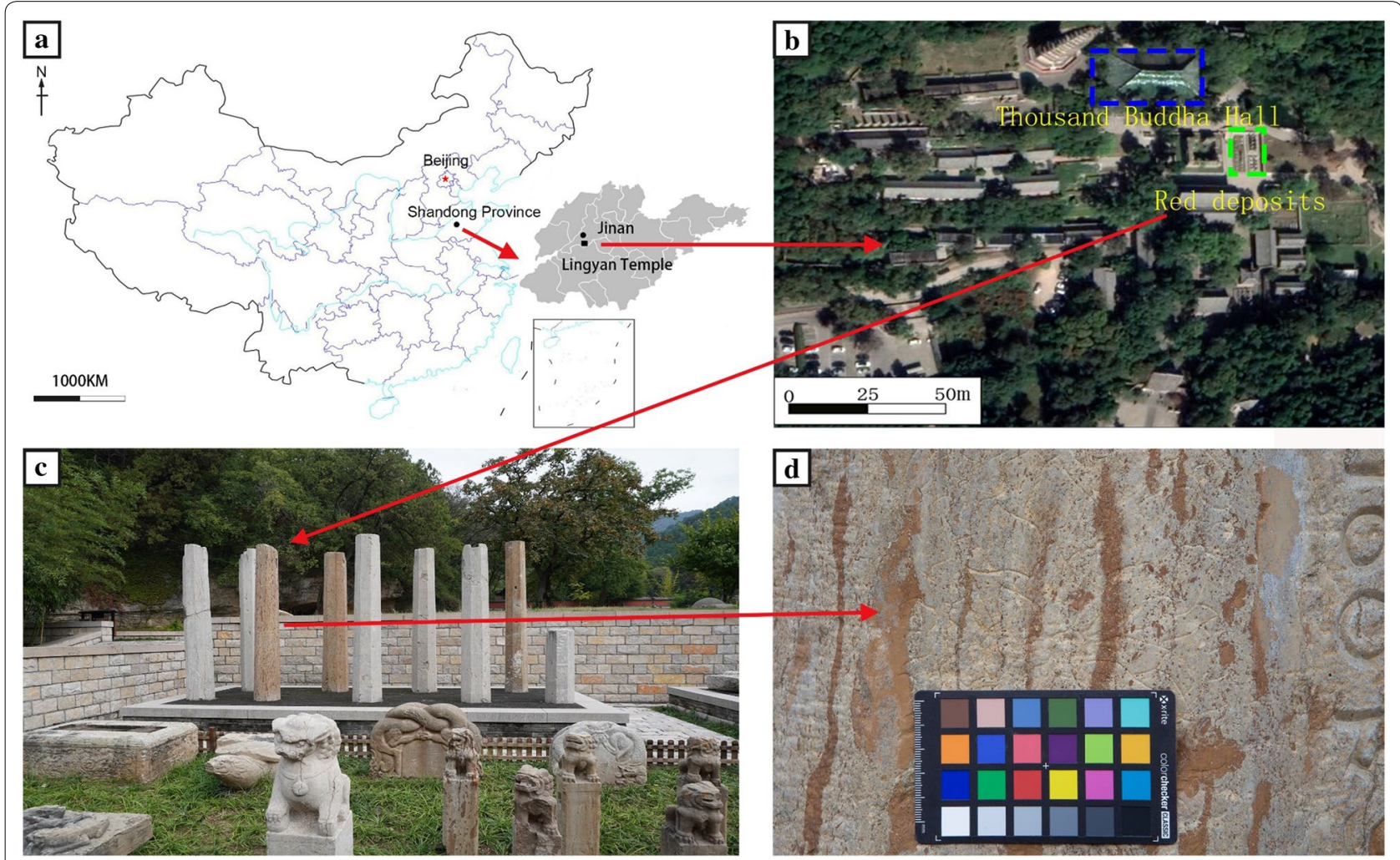

Fig. 1 Geographic location of the Lingyan Temple (a); the distribution area of the weathering stone objects in the Lingyan Temple (from Google Earth, 2019/04/13) (b); the east side of Thousand Buddha Hall (c); Red discolorations on the stone monument surface (d) 


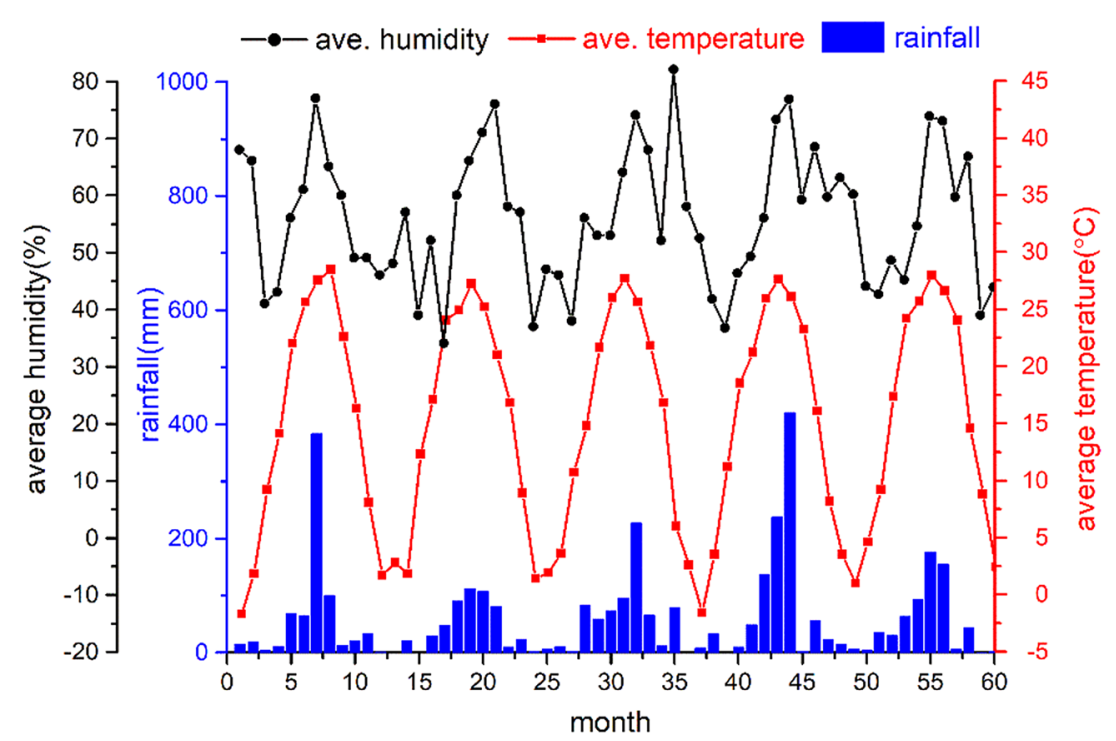

Fig. 2 Climograph of Jinan city from January 2013 to December 2017 (The data were downloaded from the climatic data center, National Meteorological Information Sharing Website)
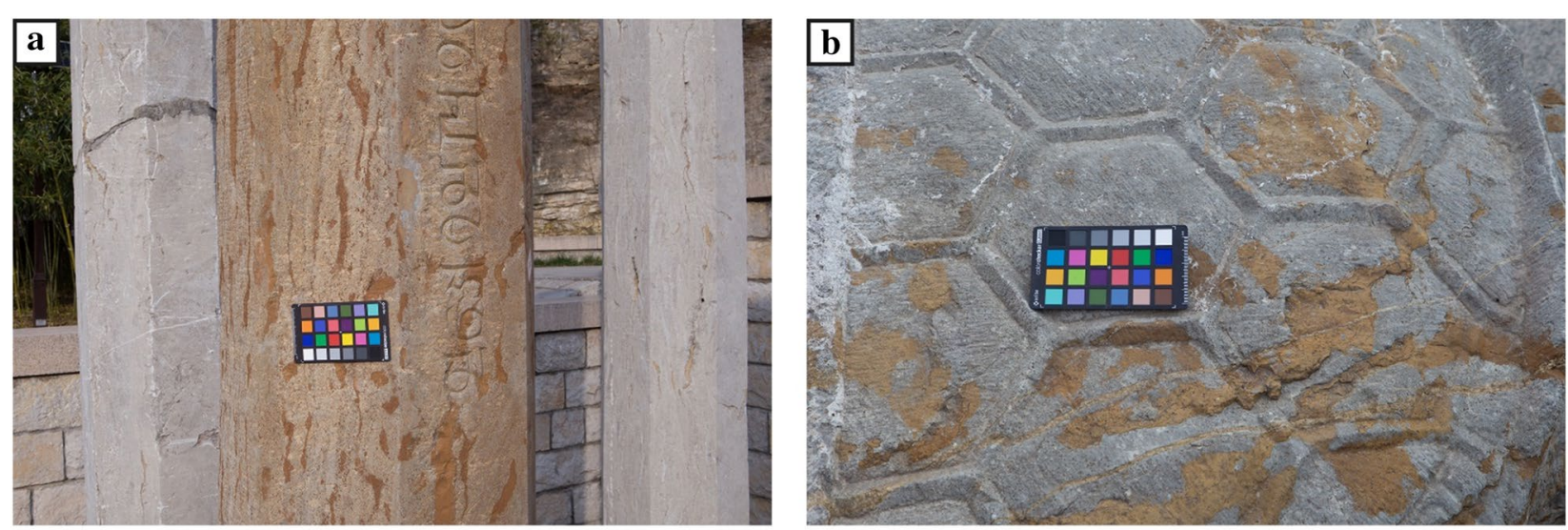

\section{c}

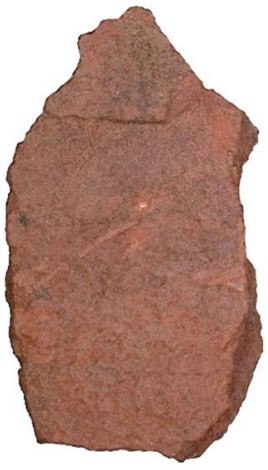

d

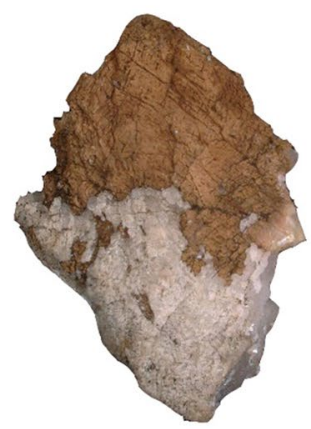

Fig. 3 Weathering features on stone objects: red discolorations on the monument (a), red discolorations on the sculpture (b), red discoloration (c), and red discoloration coexist with quartz $(\mathbf{d})$ 
(Fig. 3c). An acid-resistant mineral, such as quartz are always found on the rims of these red discolorations, indicating the formation process is dominated by acid reaction [25] (Fig. 3d).

\section{Stratum and lithology}

The original quarry of the monument was situated in the Lingyan mountain, and it is a branch of mountain Tai. The stone in this area is composed of the Ordovician system and Cambrian system limestone. And the lithologic characters of these rocks are mainly limestone and dolomitic limestone [26].

\section{Materials and analytical methods \\ Materials}

Three samples were taken from the visible fissured area of the monument using scalpel, hammer and tubes. One area was used for chemical cleaning test and colorimetric measurements. Descriptions of representative samples/areas and the analyses performed are presented in Table 1 . Before performing any analyses, the sample was first observed under a microscope and then treated with different methods for accurate analysis.

\section{Analytical methods}

\section{Stereo light microscope (SLM)}

The microscopic image of the sample was obtained by VHX-6000 ultra-depth-of-field three-dimensional video microscope (Keyence, Japan). The lens was VH-ZST, and the magnification was 20-2000. The sample was used without further treatment.

\section{$X$-ray fluorescence $(X R F)$}

Analysis of the sample was performed with a Shimadzu EDX-800HS instrument (Shimadzu, Japan) equipped with a rhodium X-ray tube. The measuring voltage is $50 \mathrm{kV}$, and the measuring times are $100 \mathrm{~s}$. The sample was crushed into a fine powder with a pestle and mortar.

\section{$X$-ray diffraction (XRD)}

The mineralogical composition of samples was determined by XRD analysis with a Rigaku Ltd Rint2000 diffractometer $(\mathrm{Cu} \mathrm{K \alpha}$ radiation, $40 \mathrm{kV}, 40 \mathrm{~mA}$, angle $5^{\circ}-75^{\circ}$, scanning speed of $4^{\circ} / \mathrm{min}$, step size $0.02^{\circ}$ ) and XRD data were analyzed using Jade software. The sample was crushed into a fine powder with a pestle and mortar.

\section{Fourier Transform Infrared Spectroscopy (FT-IR)}

The chemical bonds of the sample were measured in a diamond cell by a Nicolet iN10 Fourier transform infrared spectrometer (Thermo Scientific Corporation). The experiment set the acquisition mode (spectral range of $4000-450 \mathrm{~cm}^{-1}$ ) to attenuated total reflection (ATR), the spectral resolution is $4 \mathrm{~cm}^{-1}$ and the number of scans is 64. Each sample was scanned at $25^{\circ} \mathrm{C}$ and the data acquisition system used was OMNIC. The sample was crushed into a fine powder with a pestle and mortar.

\section{Raman spectroscopy}

A Renishaw inVia Raman spectrometer coupled with a $100 \times$ objective lens is employed for the identification of

\section{Table 1 Characteristics of the samples and an example of an area treatment with chemical cleaning}

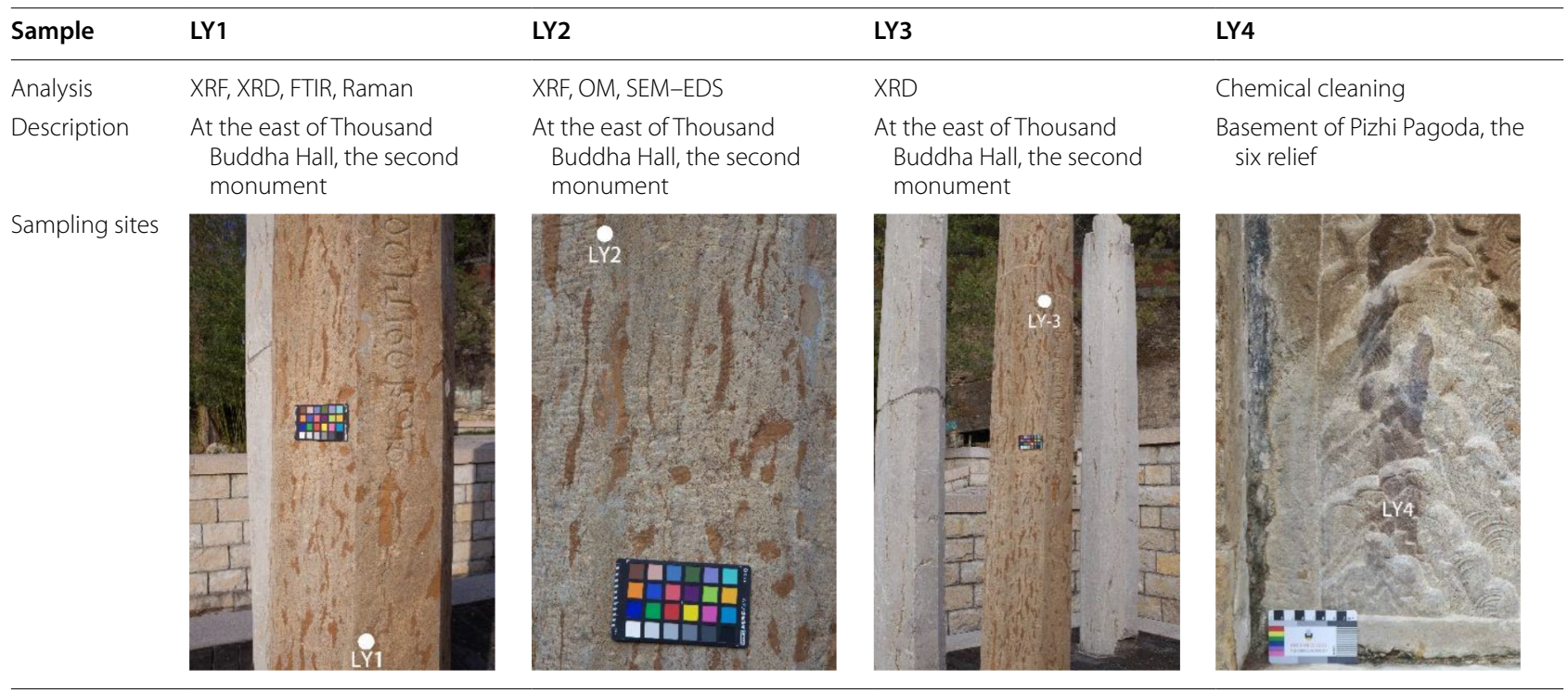


red discolorations (Raman). The $532 \mathrm{~nm}$ red laser is used and the spectrum is recorded for $2 \times 100 \mathrm{~s}$. The spectral range investigated was between 200 and $1000 \mathrm{~cm}^{-1}$. Acquisition times were $30 \mathrm{~s}$ and the spectral resolution was $2 \mathrm{~cm}^{-1}$ for the diode laser. The red discoloration was peeled off and crushed into a fine powder between two glass slides.

\section{Scanning Electron Microscope with energy dispersive X-ray spectrometry (SEM-EDS)}

Backscattered electron images investigations (BSE) were carried out by a Tescan Vega 3 XMU scanning electron microscope (Czech Republic) equipped with an EDS detector of Bruker Nano Gmbh 610 M (Germany). Observations were carried out on the sample surface section and on polished cross-sections. Part of the sample fragment was used without further treatment, the other sample fragment was mounted in epoxy resin, and was polished with metallographic sandpaper \#600, \#1000, \#1500, \#2000, \#2500 and size of $0.5 \mu \mathrm{m}$ lapping pastes. Before an examination, the sample was coated with gold.

Table 2 XRF analytical results of red discolorations

\begin{tabular}{llllll}
\hline Sample & \multicolumn{6}{l}{ Element content $(\boldsymbol{w t} \%)$} \\
\cline { 2 - 6 } & $\mathbf{C a}$ & $\mathbf{F e}$ & $\mathbf{S i}$ & $\mathbf{M n}$ & $\mathbf{K}$ \\
\hline LY1 & 85.4 & 7.7 & 3.4 & 1 & 1.3 \\
LY2 & 84.7 & 5.7 & 4.9 & 1.3 & 1.3 \\
\hline
\end{tabular}

\section{Color measurements}

Color measurements were determined using a spectrophotometer CM-26d, with the standard illuminant D65 and observer at $10^{\circ}$. Yxy space expresses the XYZ tristimulus values in terms of $\mathrm{x}$ and $\mathrm{y}$ chromaticity coordinates, somewhat analogous to the hue and saturation coordinates of HSV space. Spectral response closely matching the CIE (1931) standard observer curves. In each area, measurements were conducted at 9 points.

\section{Results and discussion}

The XRF measurements were carried out on the red area of the LY1 and LY2 sample. In each colored area, three points were analyzed and an average was calculated. Table 2 shows the red discolorations mainly contain silicon $(\mathrm{Si})$, calcium $(\mathrm{Ca})$, iron $(\mathrm{Fe})$, manganese $(\mathrm{Mn})$, and potassium (K). The amount of calcium is as high as 84.7$85.4 \mathrm{wt} \%$, and silicon is $3.4-4.9 \mathrm{wt} \%$. The percentage of iron (5.7-7.7 wt \%), manganese (1-1.3 wt \%), and potassium $(1.3 \mathrm{wt} \%)$ is also very high in the red area. Thus, the red discoloration is corresponding to the presence of iron. Furthermore, it is worth noting that the thick target background limits the sensitivity for determining a light elemental (i.e. $\mathrm{H}, \mathrm{C}, \mathrm{O}$ ), which also acts effectively in the chromatic alteration process.

In order to identify the chemical composition, the reference intensity ratio (RIR) method was used to analyze the data, rather than the intensity of the peak channel alone [27]. Figure 4 illustrates the XRD patterns of the red discolorations (LY1) and unaltered stone (LY3). The mineralogical composition of red discolorations contained large quantities of calcite (77.9\%), and

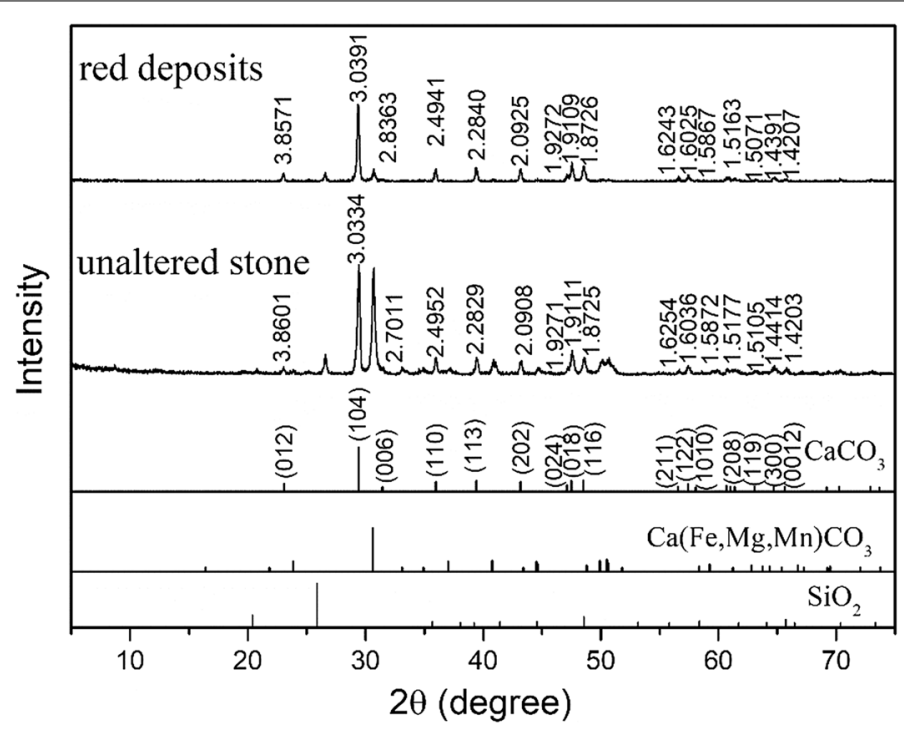

Fig. 4 XRD patterns of the red discolorations 
remarkably high amounts of quartz (15.3\%) and kutnohorite (6.8\%). Similar composition was detected in the unaltered stone (LY3) and consisted of $45.9 \%$ calcite, $11.8 \%$ quartz and $42.4 \%$ kutnohorite. The high concentration of $\mathrm{Ca}$ can be accounted for the calcite content, whereas kutnohorite is not responsible for the higher Fe content. Some iron-compounds were apparently below the detection limit (5\%) [28]. Furthermore, in comparison with the unaltered stone (LY3), it is clear that the $\mathrm{d}$-space values of the weathered stone objects (LY1) have a slight shift of (012), (202), (104) and (0012) peaks, and the structure change is always associated with acid corrosion $[29,30]$.

It is generally accepted that the Raman band positions are specific to particular chemical groups, and it is extra sensitive to the short-range order, which is a widely used characterization of weathered samples [31]. Figure 5 presents the Raman spectra of the red grain in the LY1 sample. The result showed in good agreement with the rust (around 225, 243, 292, 408, 497 and $610 \mathrm{~cm}^{-1}$ ), which is an insoluble dark red powder [32]. In the red discoloration sample, hematite can be accounted for the high concentration of Fe content. The mineral formation process is frequently associated with dissolution, precipitation and oxidation of iron ions. Dissolution occurs by the adsorption of protons to iron compound surface sites, which results in the promotion of Fe detachment from the bulk oxide through the weakening of the $\mathrm{Fe}-\mathrm{O}$ bonds [25].

As regards spectroscopic investigations, FTIR analysis cleared up the bonding of LY1 sample (Fig. 6). From the spectrum, the weak peaks at $445 \mathrm{~cm}^{-1}$ [33] and $739 \mathrm{~cm}^{-1}$ [34] assigned to the $\mathrm{Fe}-\mathrm{O}$ band for the rust. The stretching vibration of $\mathrm{Mn}-\mathrm{O}$ band and $\mathrm{Fe}-\mathrm{C}$ band

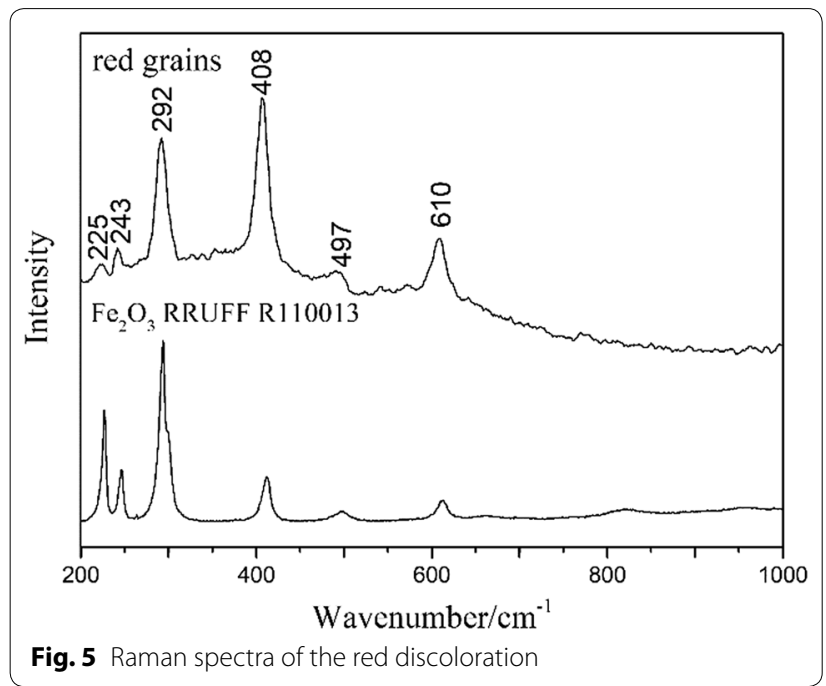

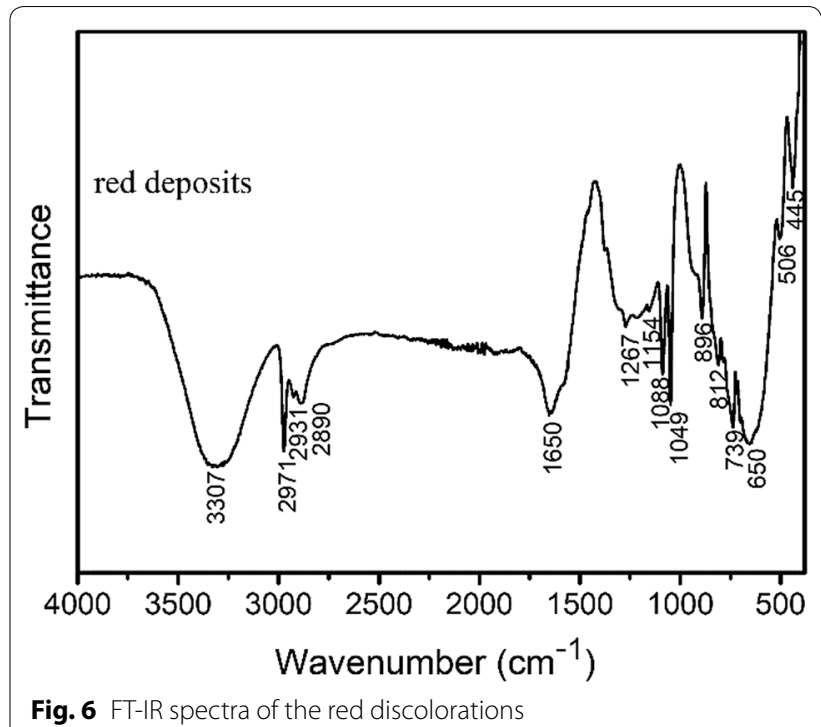

occurred at $506 \mathrm{~cm}^{-1}$ and $1154 \mathrm{~cm}^{-1}$ is associated with kutnohorite [35, 36]. Moreover, the peaks at 2890 and $1049 \mathrm{~cm}^{-1}$ attributed to the presence of $\mathrm{Fe}-\mathrm{OH}$ groups [37]. The hydrated group indicates that water plays a crucial role in the discoloration process.

The SLM observations and SEM-EDS analysis were carried out on untreated sample surface and polished cross-section (Fig. 7). In the surface section of LY2, plenty of etching pits present on the weathering surface (Fig. 7a). A large number of particles present as lamella and granular structure (Fig. 7b). These particles contained $\mathrm{Al}, \mathrm{Si}, \mathrm{K}, \mathrm{Ca}$, and Fe elements, none $\mathrm{S}$ or $\mathrm{N}$ elements was detected, as shown in Table 3. Carbonic acid works effectively in the reaction process. Moreover, the cross-section of LY2 shows a loose structure and a red layer with $20 \mu \mathrm{m}$ thickness on the surface of the weathered stone (Fig. 7c), which contained $49.8 \% \mathrm{Fe}$ and $33.6 \%$ $\mathrm{Ca}$ elements in the light of the EDS results (Table 3). Fe concentrated in the red discoloration area of the sample (Fig. 7d). The elemental distributions of red discolorations were determined through EDS mapping analysis, as shown in Fig. 7e. Corresponding with the BSE image (Fig. 7d). The result confirms that $\mathrm{Fe}, \mathrm{Mn}, \mathrm{Si}$ and $\mathrm{Ca}$ exist in the sample and $\mathrm{Fe}, \mathrm{Si}$ aggregates in the weathering stone surface. Combining the above XRD results, it further demonstrates that the corrosion of kutnohorite $\left(\mathrm{Ca}(\mathrm{Fe}, \mathrm{Mg}, \mathrm{Mn}) \mathrm{CO}_{3}\right)$ promotes the formation of iron oxide sediments, and the weathering process stopped in the layer composite of quartz.

In general, the discolorations have the crystallographic structure of hematite and are characterized by the presence of $\mathrm{Fe}-\mathrm{OH}$ bonds. Discoloration of the monuments leads to the crystal structure change of calcite, and it is 

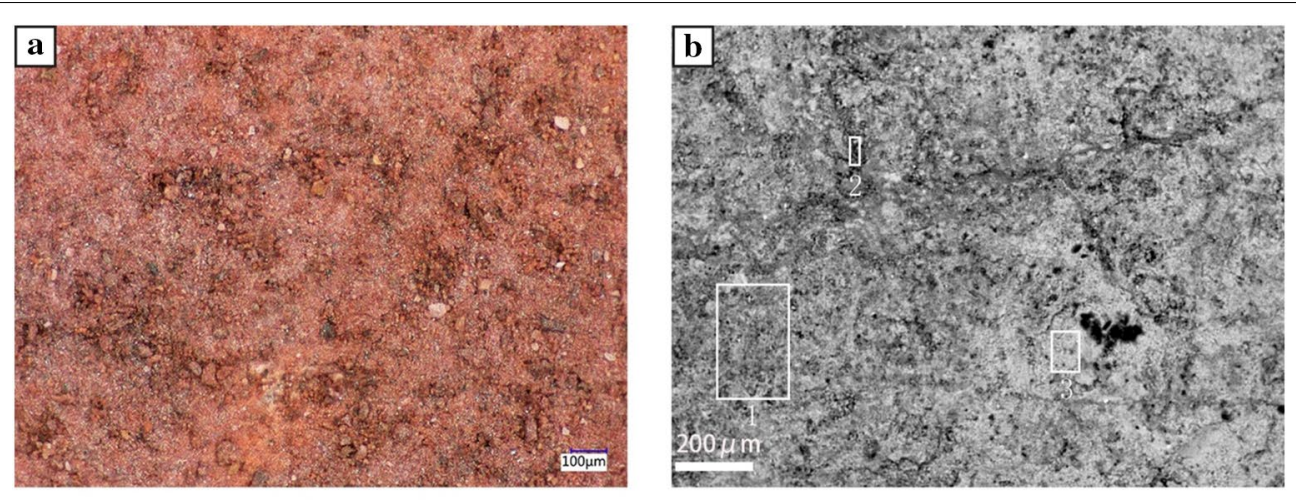

\section{c}
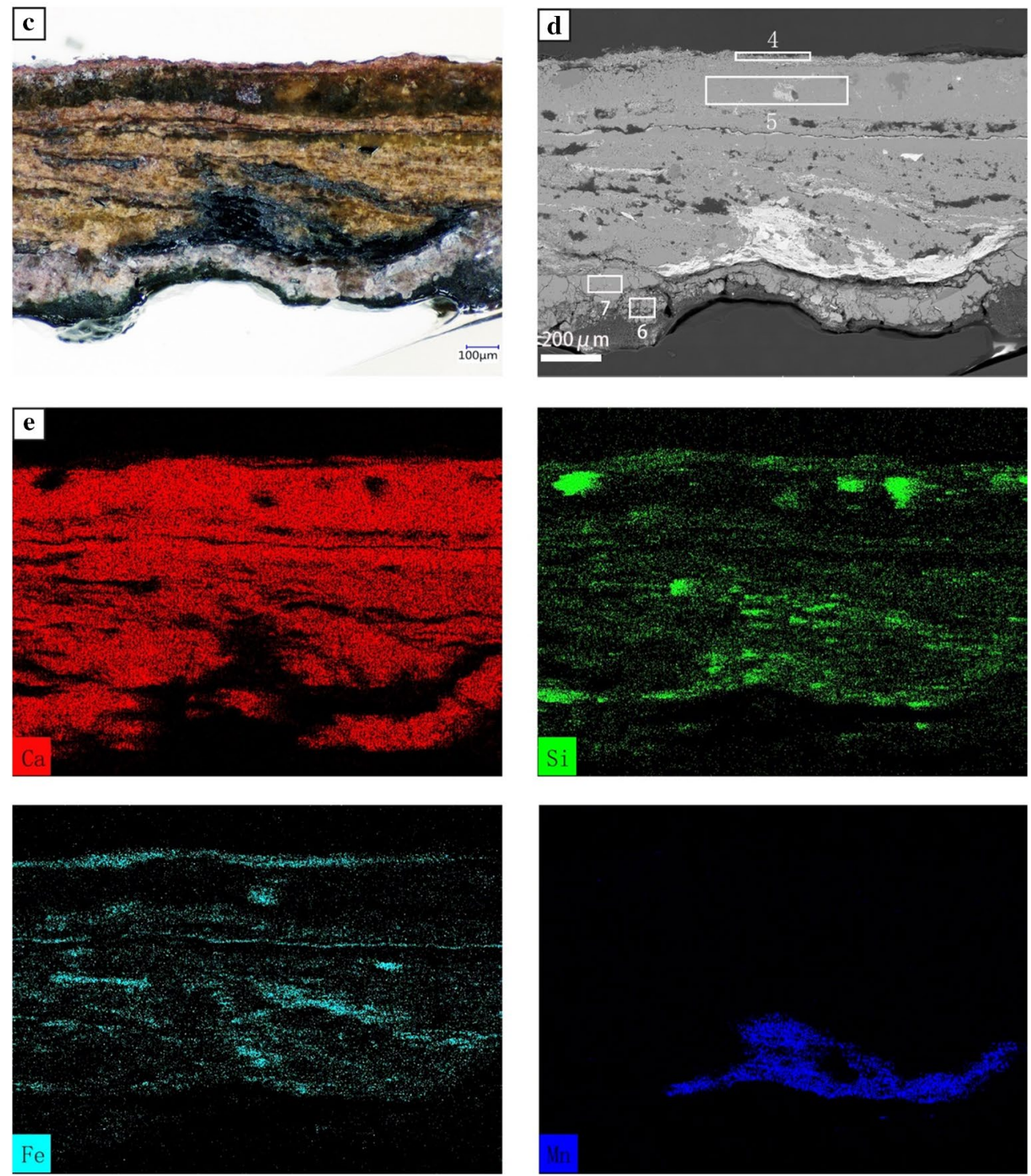

Fig. 7 The surface section of the LY2 (a), BSE image of the surface section (b), the cross section of the LY2 (c), BSE image of the cross section (d), and the relative EDS mapping (e) 
Table 3 EDS analysis of positions shown in Fig. 7

\begin{tabular}{|c|c|c|c|c|c|c|}
\hline \multirow[t]{2}{*}{ Position number } & \multicolumn{6}{|c|}{ Element content (wt \%) } \\
\hline & $\overline{\mathrm{Al}}$ & $\mathrm{Si}$ & $\mathrm{K}$ & $\mathrm{Ca}$ & $M n$ & $\mathrm{Fe}$ \\
\hline 1 & 4.7 & 7.2 & 1.9 & 20.1 & & 66.1 \\
\hline 2 & 3.1 & 4.4 & 1.5 & 34.1 & & 56.9 \\
\hline 3 & 3.7 & 5.3 & 1.3 & 2.8 & & 86.8 \\
\hline 4 & 5.3 & 8.6 & 2.7 & 33.6 & & 49.8 \\
\hline 5 & & 3.6 & & 81.9 & 1.9 & 12.7 \\
\hline 6 & 2.7 & 3.5 & & 84.4 & & 9.4 \\
\hline 7 & & & & 97.1 & & 2.9 \\
\hline
\end{tabular}

inevitably bound up with the acid dissolution process. Sulfur and nitrogen compounds were not detected in the discoloration area. Other acid compounds, such as carbonic acid has become the corrosion controlling factor. Compared with unaltered stone, the sharp decrease of kutnohorite in the discoloration area led us to hypothesize the in situ dissolution of kutnohorite [38] (Fig. 4). The FT-IR results are borne out of the hypothesis and detected that the transformation from kutnohorite to rust on the red discolorations was caused by the hydration process [39]. Thus, the formation process of red discolorations was composed of the following reactions. Firstly, carbon dioxide $\left(\mathrm{CO}_{2}\right)$ in the air reacts with the rainwater and forms a weak acid (carbonic acid). When carbon acid meets calcite and kutnohorite, which is a natural process, termed karst dissolution, that has been the active agent in limestone dissolution over geologic time. Subsequently, general hydrogenation of iron ions and decomposition of calcium bicarbonate occurred at the surface area of sculpture [40]. The reaction product with a low solubility constant (Ksp) is inclined to form the insoluble substance, such as the rust. The reaction process is presented by Eqs. (1), (2), (3) and (4). The other ions (i.e. $\mathrm{Mg}^{2+}, \mathrm{Mn}^{2+}$ ) were difficult to be oxidized, and inclined to leach from the stone with water run-off.

$$
\begin{aligned}
& \mathrm{Fe}^{2+}+2 \mathrm{HCO}_{3}^{-} \rightarrow \mathrm{Fe}(\mathrm{OH})_{2}+2 \mathrm{CO}_{2}\left(\mathrm{Ksp}=8 \times 10^{-16}\right) \\
& 4 \mathrm{Fe}(\mathrm{OH})_{2}+2 \mathrm{H}_{2} \mathrm{O}+\mathrm{O}_{2} \rightarrow 4 \mathrm{Fe}(\mathrm{OH})_{3}\left(\mathrm{Ksp}=4 \times 10^{-38}\right) \\
& 2 \mathrm{Fe}(\mathrm{OH})_{3} \rightarrow \mathrm{Fe}_{2} \mathrm{O}_{3}+3 \mathrm{H}_{2} \mathrm{O}
\end{aligned}
$$

$\mathrm{Ca}\left(\mathrm{HCO}_{3}\right)_{2} \rightarrow \mathrm{CaCO}_{3}+\mathrm{H}_{2} \mathrm{O}+\mathrm{CO}_{2}\left(\mathrm{Ksp}=3.36 \times 10^{-9}\right)$

In summary, a schematic diagram of the red discoloration formation process in the monument surface was shown in Fig. 8. The composition of the monument played an important role in the efflorescence process. Firstly, rainwater reacts with carbon dioxide to produce carbonic acid. Subsequently, the acid solution absorbed and erode the stone objects, and ions in corrosive solution changed via a series of processes, such as evaporation, oxidation, and leaching. Reaction product with a low water solubility discoloration on the stone object surface (i.e. rust). It was finally resulting in the formation of red

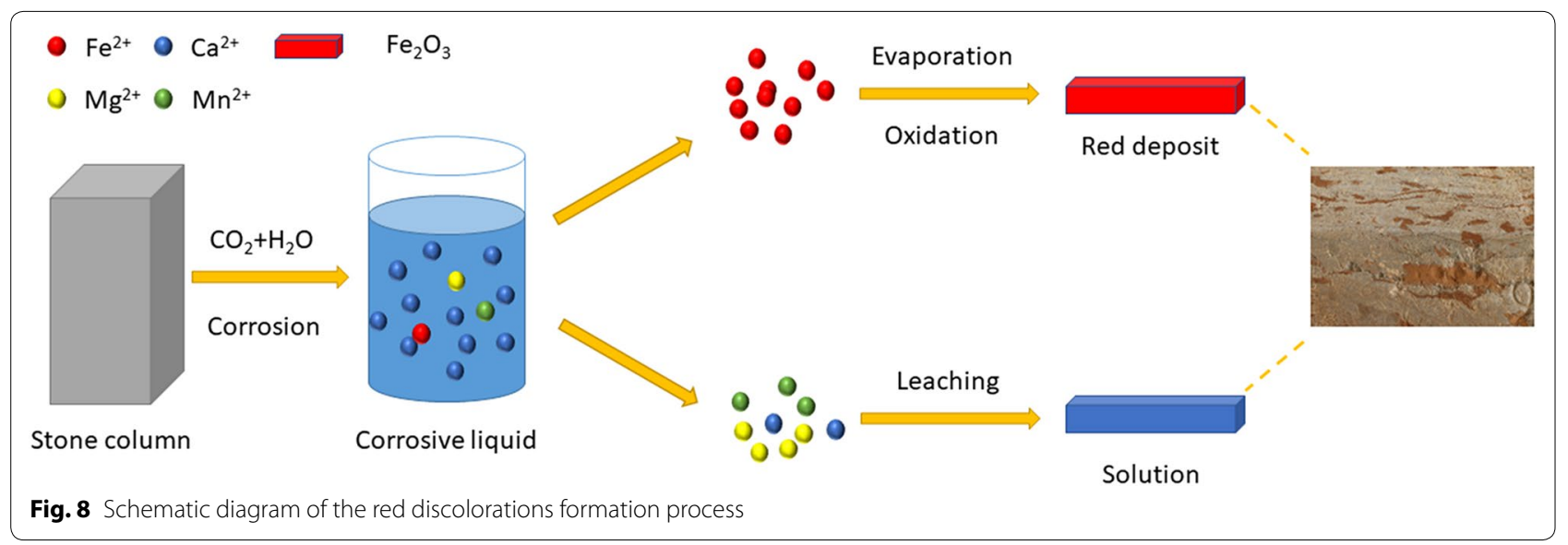


discoloration. It is a physical and chemical effloresce process during water-rock interaction. Leaching is a weathering process that affects some stone parts, especially the stone surface that is mainly composed of the mineral calcite and kutnohorite. It occurs due to rainwater flowing on the stone object surface and leads to the creation of micro karst and red discoloration. Flaking is another effloresce process that starts with alteration micro karst. In the wet discoloration, heavy rains and high value of $\mathrm{RH}$ induce the ongoing loss of cohesion between grains. These deterioration processes can be traced essentially to synergetic effects of total monthly rainfall and relative humidity. A similar phenomenon on the granite surface was found in Egypt, which created by the effect of washing and leaching of alkaline silicates.

In the field of stone object conservation, red discoloration is usually considered to be harmful and dangerous because of its ugly appearance and thermal stress fatigue. Surface temperature and thermal gradients created by insolation depend on the thermal characteristics of the stone object. The volumetric change of $\mathrm{Fe}_{2} \mathrm{O}_{3}$ on thermal expansion and contraction shows a sharp difference from $\mathrm{CaCO}_{3}$, which promotes micro-fracturing of surface grains. As a result, the removal of the red discoloration is considered to protect the objects. A cleaning method for the removal of red discolorations from stone objects must respect the chemical and physical nature of the material of the stone object. In the previous research, the removal of red discoloration from the stone objects by using Sodium ethylene diammonium tetraacetate (EDTA-2Na) proved to be an effective cleaning procedure [41]. EDTA-2Na is a weak acid that facilitates the removal of $\mathrm{Fe}_{2} \mathrm{O}_{3}$ through the chelating process and can be classified as a soft cleaning procedure [42]. So, EDTA poultices have been applied on the stone surfaces for removing the red discolorations. It is composed of $5 \mathrm{~g}$ of Sodium ethylene diammonium tetraacetate and $5 \mathrm{~g}$ of sodium bicarbonate, all $100 \mathrm{ml}$ of water [43]. This technique adopts the following procedures. First, wetting the stone surface by distilled water to soften the staining crusts. Next, applying the poultices to the discoloring area and wipe it with absorbent cotton five times. Last, washing the stone surface by de-ionized water to prevent the influence of sodium three times. Figure 9 shows the cleaning effect of the LY4 sample. It can be seen that most of the red discolorations on the stone sculpture were removed completely after the cleaning, while the shape of the delicate carvings and the stone surface remains unchanged. In order to achieve a more

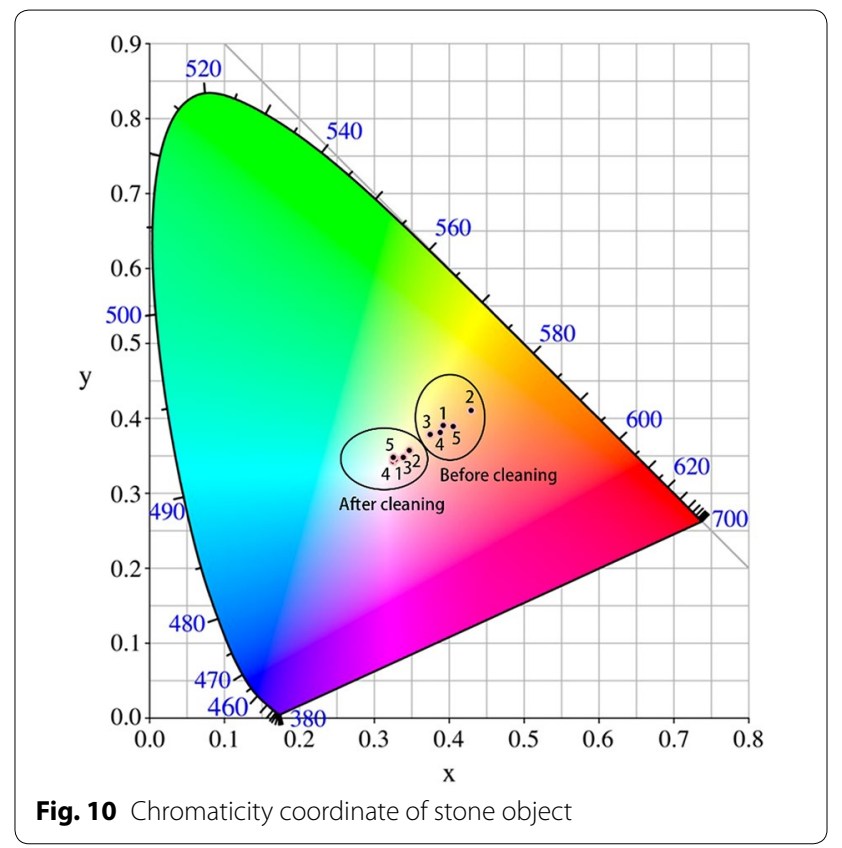

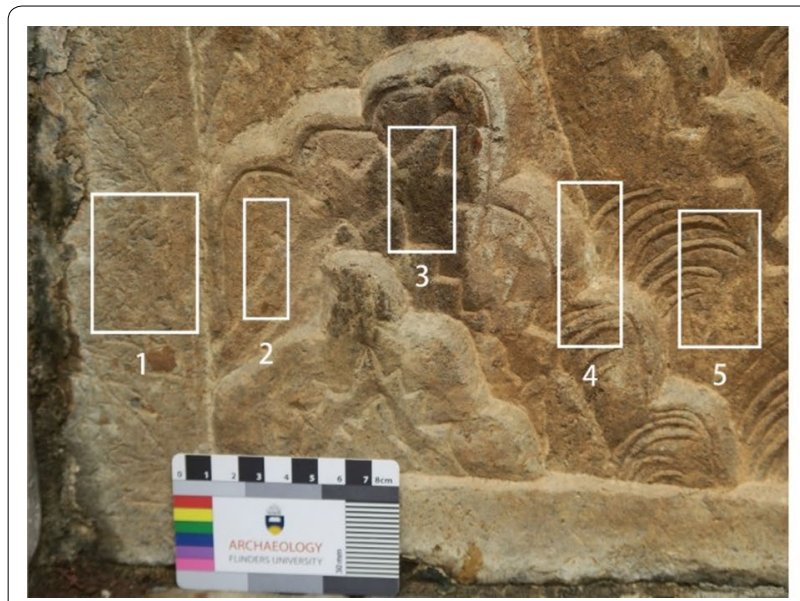

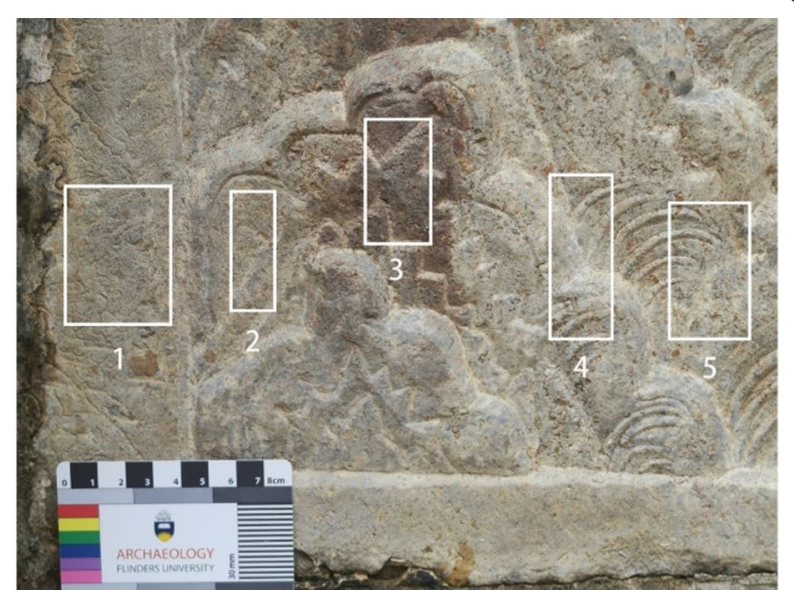

Fig. 9 Photographs of a stone object before cleaning (a) and after cleaning (b) 
objective description, the color coordinates of the stone objects were drawn in the chromaticity diagram (Fig. 10). The results show that each cleaning area is located in the white region of chromaticity coordinate, and leaving the underlying stone unchanged. The above phenomenon indicates that the EDTA-2Na bind with an iron element to form water-soluble complexes effectively. This cleaning technique has an excellent ability for removing and stabilizing the discoloration area and modulate the aesthetic value of the stone object, as discussed by Moropoulou [44]. The washing procedures tested during the present study also show the usage of sodium bicarbonate, which accelerates the $\mathrm{Fe}_{2} \mathrm{O}_{3}$ dissolution process [45]. Generally speaking, the cleaning method depends on the composition of red discoloration.

\section{Conclusions}

This research concentrates on the formation, composition, and possible removal of red discolorations that stain the stone surface. Multi analysis methods have been conducted to explain the weathering mechanism of red discoloration in Lingyan Temple, Jinan City, Shandong Province, China. The synergetic effect of temperature, monthly rainfall, relative humidity, and mineral composition of stone objects define the weathering behavior in this area. The red discoloration is due to the presence of rust concentrated in the kutnohorite and calcite crystal surface. The chemical group of the iron composition shows hydration, carbonation, and the oxidation process. These data excluded the origin of red stains from environmental contamination or man-made pollution. The rust responsible for the red stains came from the presence of kutnohorite as accessory phases in the stone objects. Under conditions of sufficient water and $\mathrm{CO}_{2}$, the carbonic acid solution induces calcite and kutnohorite dissolution, and form lots of etching pits on the stone objects surface. Subsequently, leaching, hydration, carbonation, and oxidation process operate synergistically on the roughness sculpture surface and likely to form a discoloration of rust. In summary, it can be defined that the rigid red discolorations on the limestone surface were formed through the effect of washing and leaching of a stone object by rainwater.

EDTA-2Na were selected as stone-washing chemicals for the use in Fe-contaminated stone objects based on their Fe-extraction efficiency, cost-effectiveness, and relatively low environmental impacts. The optimal conditions for on-site stain washing with EDTA-2Na appear to be an EDTA-2Na concentration of $5 \% \mathrm{wt}$, five washing treatments, and three rinses with water to eliminate excess sodium, while the stone surface still maintains its original cohesion, appearance, and roughness.

\section{Abbreviations}

UNESCO: United nations educational, scientific and cultural organization;

EDTA-2Na: Ethylenediamine tetraacetic acid disodium salt; $\mathrm{RH}$ : Relative humidity; XRF: X-ray fluorescence spectroscopy; XRD: X-ray diffraction; Raman: MicroRaman spectroscopy; FTIR: Fourier transform infrared spectroscopy; SEM-EDS: Scanning electron microscopy-energy dispersive $\mathrm{X}$-ray analysis.

\section{Acknowledgements}

Authors would like to thank the anonymous reviewers for their valuable comments that helped improve the quality of this paper. Besides, the authors are delighted to express their great gratitude to the Researchers Yunqiong Wang at the Lingyan Temple, Xuening Wang at the Institute of Heritage Conservation and Restoration Shandong Province for their kind support and assistance.

\section{Authors' contributions}

QM provided support and guidance for this study. JZ and ZL carried out literature and examination. CW and YC provided the samples and help the remove test in situ. SW was involved in the initial concept of the examination. All authors read and approved the final manuscript.

\section{Funding}

The research is financially supported by cooperation conservation project of Lingyan Temple between the Institute of Cultural Heritage of Shandong University and the Shandong Provincial Conservation Center.

\section{Availability of data and materials}

The datasets used during this study are available from the corresponding author on reasonable request.

\section{Competing interests}

The authors declare that they have no competing interests.

\section{Author details}

${ }^{1}$ Institute of Cultural Heritage and History of Science \& Technology, University of Science and Technology Beijing, Beijing 100083, China. ${ }^{2}$ Shandong Cultural Relic Conservation and Restoration Center, Jinan 250014, Shandong Province, China. ${ }^{3}$ International Joint Research Laboratory of Environmental and Social Archaeology, Shandong University, Qingdao 266237, Shandong Province, China.

Received: 30 January 2020 Accepted: 16 May 2020

Published online: 09 June 2020

\section{References}

1. Török A, Licha T, Simon K, Siegesmund S. Urban and rural limestone weathering; the contribution of dust to black crust formation. Environ Earth Sci. 2011;63(4):675-93. https://doi.org/10.1007/s12665-010-0737-6.

2. Kapsalas P, Zervakis M, Maravelaki-Kalaitzaki P. Evaluation of image segmentation approaches for non-destructive detection and quantification of corrosion damage on stonework. Corros Sci. 2007;49(12):4415-42. https://doi.org/10.1016/j.corsci.2007.03.049.

3. Bams V, Dewaele S. Staining of white marble. Mater Charact. 2007;58(11):1052-62. https://doi.org/10.1016/j.matchar.2007.05.004.

4. Slaton D, Normandin KC. Masonry cleaning technologies. J Archit Conserv. 2005;11(3):7-31. https://doi.org/10.1080/13556207.2005.10784950.

5. Schabereiter-Gurtner C, Piñar G, Vybiral D, Lubitz W, Rölleke S. Rubrobacter-related bacteria associated with rosy discolouration of masonry and lime wall paintings. Arch Microbiol. 2001;176(5):347-54. https://doi. org/10.1007/s002030100333.

6. Saiz-Jimenez C. Microbial melanins in stone monuments. Sci Total Environ. 1995;167(1):273-86. https://doi.org/10.1016/0048-9697(95)04588-R.

7. Realini M, Colombo C, Sansonetti A, Rampazzi L, Colombini MP, Bonaduce I, Zanardini E, Abbruscato P. Oxalate films and red stains on carrara marble. Ann Chim. 2005;95:217-26. https://doi.org/10.1002/adic.20059 0024. 
8. Bruni S, Carlati F, Binachi CL, Zanardini E, Sorlini C. Spectroscopic investigation of red stains affecting the carrara marble facade of the certosa of pavia. Archaeometry. 1995;37(2):249-55. https://doi. org/10.1111/j.1475-4754.1995.tb00741.x.

9. Cantisani E, Cuzman OA, Vettori S, Chelazzi L, Ciattini S, Ricci M, Manganelli DFR, Chiarantini L, Garzonio CA. A multi-analytical approach for the study of red stains on heritage marble. Analyst. 2019;144(7):2375-86. https://doi.org/10.1039/C8AN02426J.

10. Konkol N, McNamara C, Sembrat J, Rabinowitz M, Mitchell R. Enzymatic decolorization of bacterial pigments from culturally significant marble. J Cult Herit. 2009;10(3):362-6. https://doi.org/10.1016/j.culher.2008.10.006.

11. Petushkova JP, Lyalikova NN. Microbiological degradation of lead-containing pigments in mural paintings. Stud Conserv. 1986;31(2):65-9. https ://doi.org/10.1179/sic.1986.31.2.65

12. El-Gohary M. Experimental tests used for treatment of red weathering crusts in disintegrated granite-Egypt. J Cult Herit. 2009;10(4):471-9. https://doi.org/10.1016/j.culher.2009.01.002.

13. Zeng ZX. A study on the relevance between the 40 statues of arhats and 500 statues of arhats in the lingyan buddhist temple at changqing. 2nd Int Conf Mod Educ Soc Sci. 2016. https://doi.org/10.12783/dtssehs/mess2 016/9766.

14. Vidal F, Vicente R, Mendes SJ. Review of environmental and air pollution impacts on built heritage: 10 questions on corrosion and soiling effects for urban intervention. J Cult Herit. 2019;37:273-95. https://doi. org/10.1016/j.culher.2018.11.006.

15. Gibeaux S, Vázquez P, Kock TD, Veerle C, Céline T-S. Weathering assessment under $X$-ray tomography of building stones exposed to acid atmospheres at current pollution rate. Constr Build Mater. 2018;168:187-98. https://doi.org/10.1016/j.conbuildmat.2018.02.120.

16. Shumka L, Ciftci C. Relative rate of durability towards influence of water in stone degradation: case study of lead Mosque in Shkodra (northwest Albania). J Int Environ Appl Sci. 2018;13(2):105-9.

17. Winkler EM. The importance of air pollution in the corrosion of stone and metals. Eng Geol. 1970;4(4):327-34. https://doi.org/10.1016/00137952(70)90022-0.

18. Baedecker PA, Reddy MM. The erosion of carbonate stone by acid rain: laboratory and field investigations. J Chem Educ. 1993;70(2):104-8. https ://doi.org/10.1021/ed070p104.

19. Vazquez P, Carrizo L, Thomachot-Schneider C, Gibeaux S, Alonso FJ. Influence of surface finish and composition on the deterioration of building stones exposed to acid atmospheres. Constr Build Mater. 2016;106:392403. https://doi.org/10.1016/j.conbuildmat.2015.12.125.

20. Turkington AV, Paradise T. Sandstone weathering: a century of research and innovation. Geomorphol. 2005;67(1):229-53. https://doi. org/10.1016/j.geomorph.2004.09.028.

21. Carol AG, Claire G, Nicole CL, Genevieve B, Robert JS. Red "staining" on marble: biological or inorganic origin? APT Bulletin. 2010;41:11-20.

22. Baedecker PA, Reddy MM, Reimann KJ, Sciammarella CA. Effects of acidic deposition on the erosion of carbonate stone-experimental results from the US National Acid Precipitation Assessment Program (NAPAP). Atmos Environ Part B. 1992;26(2):147-58. https://doi.org/10.1016/09571272(92)90018-N

23. Gauri KL, Holdren GC. Pollutant effects on stone monuments. Environ Sci Technol. 1981;15(4):386-90. https://doi.org/10.1021/es00086a001.

24. Climatic Data Center, National Meteorological Information Center, China Meteorological Administration; 2015. http://data.cma.cn/. Accessed 19 Apr 2019.

25. Pepper RA, Couperthwaite SJ, Millar GJ. Comprehensive examination of acid leaching behaviour of mineral phases from red mud: recovery of $\mathrm{Fe}$ Al, Ti, and Si. Miner Eng. 2016;99:8-18. https://doi.org/10.1016/j.minen g.2016.09.012

26. Fang YZ, Ma ZM. Study on evolution rules of groundwater dynamic environment within karst water system in Taian. Int Conf Chall Environ Sci Comput Eng. 2010;2010:286-8. https://doi.org/10.1109/CESCE.2010.117.

27. Török Á, Rozgonyi N. Morphology and mineralogy of weathering crusts on highly porous oolitic limestones, a case study from Budapest. Environ Geol. 2004;46(3):333-49. https://doi.org/10.1007/s00254-004-1036-x.

28. Fantauzzi M, Licheri C, Atzei D, Loi G, Elsener B, Rossi G, Rossi A. Arsenopyrite and pyrite bioleaching: evidence from XPS, XRD and ICP techniques. Anal Bioanal Chem. 2011;401 (7):2237-48. https://doi.org/10.1007/s0021 6-011-5300-0.
29. Al-Jaroudi SS, UI-Hamid A, Mohammed ARI, Saner S. Use of X-ray powder diffraction for quantitative analysis of carbonate rock reservoir samples. Powder Technol. 2007;175(3):115-21. https://doi.org/10.1016/j.powte c.2007.01.013.

30. Lee SW, Kim Yll, Lee KB, Bang JH, Jun CW, Jang YN. Effect of serine and arginine on the phase transition from amorphous $\mathrm{CaCO}_{3}$ and $\mathrm{CaCO}_{3} \cdot 6 \mathrm{H}_{2} \mathrm{O}$ to calcite film. Mater Trans. 2012;53(10):1732-8. https://doi. org/10.2320/matertrans.M2012164.

31. Han YJ, Aizenberg J. Effect of magnesium ions on oriented growth of calcite on carboxylic acid functionalized self-assembled monolayer. J Am Chem Soc. 2003;125(14):4032-3. https://doi.org/10.1021/ja034094z.

32. Yu WC, Polgári M, Gyollai I, Fintor K, Szabó M, Kovács I, Fekete J, Du YS, Zhou Q. Microbial metallogenesis of Cryogenian manganese ore deposits in South China. Precambrian Res. 2019;322:122-35. https://doi. org/10.1016/j.precamres.2019.01.004.

33. Li D, Teoh WY, Selomulya C, Woodward RC, Munroe P, Amal R. Insight into microstructural and magnetic properties of flame-made $y-\mathrm{Fe}_{2} \mathrm{O}_{3}$ nanoparticles. J Mater Chem. 2007;17(46):4876-84. https://doi.org/10.1039/ B711705A.

34. Silva AC, Cepera RM, Pereira MC, Lima DQ, Fabris JD, Oliveira LCA. Heterogeneous catalyst based on peroxo-niobium complexes immobilized over iron oxide for organic oxidation in water. Appl Catal B. 2011;107(3):23744. https://doi.org/10.1016/j.apcatb.2011.07.017.

35. Dubal DP, Kim WB, Lokhande CD. Surfactant assisted electrodeposition of $\mathrm{MnO}_{2}$ thin films: improved supercapacitive properties. J Alloys Compd. 2011;509(41):10050-4. https://doi.org/10.1016/j.jallcom.2011.08.029.

36. Dumitru A, Morozan A, Mirea C, Mihaiescu D, Panaiotu C, Ciupina V, Stamatin I. Inorganic copolymers based on silanes and ferrocene monomers, precursors for advanced nanostructured ceramics. Compos Sci Technol. 2005;65(5):713-7. https://doi.org/10.1016/j.compscitec h.2004.10.004.

37. Ciopec M, Negrea A, Lupa L, Davidescu CM, Negrea P. Studies regarding as $(V)$ adsorption from underground water by Fe-XAD8-DEHPA impregnated resin equilibrium sorption and fixed-bed column tests. Molecules. 2014;19(10):16082-101. https://doi.org/10.3390/molecules191016082.

38. de Faria DLA, Silva SV, de Oliveira MT. Raman microspectroscopy of some iron oxides and oxyhydroxides. J Raman Spectrosc. 1997;28(11):873-8. https://doi.org/10.1002/(SICI)1097-4555(199711)28:11\%3c873:AID-JRS17 7\%3e3.0.CO;2-B.

39. Lovley DR, Phillips EJP. Availability of ferric iron for microbial reduction in bottom sediments of the freshwater tidal potomac river. Appl Environ Microbiol. 1986;52(4):751-7. https://doi.org/10.1128/ AEM.52.4.751-757.1986.

40. Walker TR, Larson EE, Hoblitt RP. Nature and origin of hematite in the Moenkopi formation (Triassic) Colorado Plateau: a contribution to origin of magnetism in red beds. J Geophys Res Solid Earth. 1981;86(B1):317-33. https://doi.org/10.1029/JB086iB01p00317.

41. Wang YR, Zhu TQ, Yang GC, Tan X, Ye DY, Chen HT. The method to soften the concretions of ceramics in the "Nanhai I"Shipwreck of China Southern Song Dynasty (1127-1279AD). Herit Sci. 2018;6(1):1-10. https://doi. org/10.1186/s40494-018-0168-3.

42. Yao CK, Wang R, Wang ZS, Lei H, Dong XP, He CZ. Highly dispersive and stable $\mathrm{Fe}^{3+}$ active sites on 2D graphitic carbon nitride nanosheets for efficient visible-light photocatalytic nitrogen fixation. J Mater Chem A. 2019;7(48):27547-59. https://doi.org/10.1039/C9TA09201C.

43. Mahmoud MA, Abdelgawad KZ. Chelating-agent enhanced oil recovery for sandstone and carbonate reservoirs. SPE J. 2015;20(3):483-95. https:// doi.org/10.2118/172183-PA.

44. Moropoulou A, Kefalonitou S. Efficiency and countereffects of cleaning treatment on limestone surfaces-investigation on the Corfu Venetian Fortress. Build Environ. 2002;37(11):1 181-91. https://doi.org/10.1016/ S0360-1323(01)00059-2.

45. Pozo-Antonio JS, Rivas T, López AJ, Fiorucci MP, Ramil A. Effectiveness of granite cleaning procedures in cultural heritage: a review. Sci Total Environ. 2016;571:1017-28. https://doi.org/10.1016/j.scitotenv.2016.07.090.

\section{Publisher's Note}

Springer Nature remains neutral with regard to jurisdictional claims in published maps and institutional affiliations. 